Web Jurnal:

http://ejournal.kemenperin.go.id/jli

Kementerian

Perindustrian

REPUBLIK INDONESIA

\title{
Hidroksiapatit sintetik Balai Besar Keramik (BBK) sebagai material baru filter tabir surya
}

\section{Hydroxyapatite synthetic of Center for Ceramic as a novel sunscreen filter material}

\author{
Rizky Berliana Wijayanti*, Imas Panca Wardhani, dan Kristanto Wahyudi \\ Balai Besar Keramik \\ Jalan Ahmad Yani No 392, Bandung, Indonesia \\ * e-mail: rizkyberliana@gmail.com
}

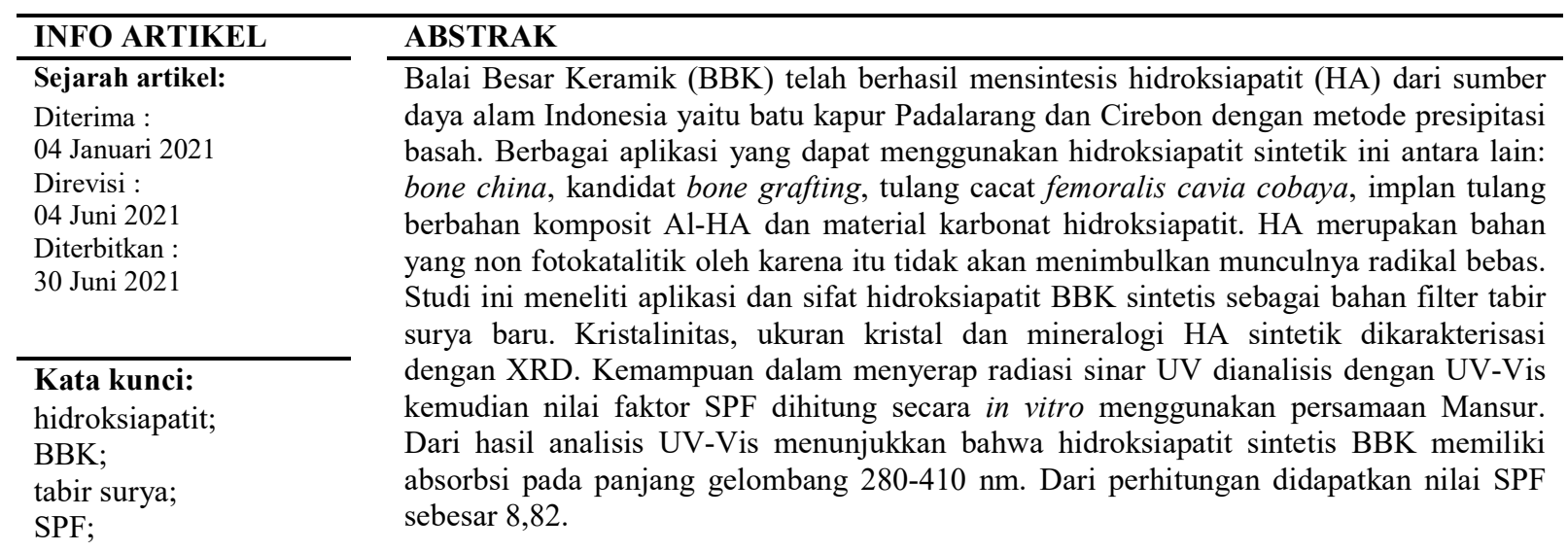

Mansur

\begin{tabular}{l}
\hline Keywords: \\
hydroxyapatite \\
BBK; \\
sunscreen; \\
SPF; \\
Mansur
\end{tabular}

\begin{abstract}
Center for Ceramic (BBK) had successfully to synthetized hydroxyapatite (HA) from natural resources of Indonesia, which was Padalarang and Cirebon limestones by wet precipitation method. There were various applications of synthetic hydroxyapatites such as : bone china body, bone grafting candidate, cavia cobaya femoral defect bone, bone implant based on composite Al-HA and carbonated hydroxyapatite material. Hydroxyapatite is not a photocatalytic material therefore it would not induce to a evocation of free radicals. This study investigated the application and properties of synthetic hydroxyapatite $B B K$ as a novel sunscreen filter material. Crystallinity, crystallite size and mineralogy of synthetic HA were characterized by XRD. The ability to absorb UV radiation was analyzed by UV-Vis then SPF factor value calculated based on Mansur equation. This material showed good absorption in the wavelength of 280-410 $n m$. The SPF value measurement was 8,82 .
\end{abstract}

(C) 2021 Penulis. Dipublikasikan oleh Baristand Industri Padang. Akses terbuka dibawah lisensi CC BY-NC-SA

\section{Pendahuluan \\ Radiasi sinar ultra violet (UV) menimbulkan masalah bagi kesehatan kulit manusia, diantaranya: kulit terbakar, penuaan dan kanker kulit. UV yang dipancarkan sinar matahar terdiri atas 3 jenis yaitu UVA (315-400 nm), UVB (280-315 nm) dan UVC (200-280 nm)(Egambaram et al., 2020). Sinar UVC diserap oleh}

lapisan ozon sehingga tidak teremisikan ke permukaan bumi, sedangkan UVB hanya sebagian yang diemisikan dan UVA seluruhnya diemisikan ke bumi. Penetrasi UVB hanya sampai lapisan kulit epidermis, menyebabkan iritasi pada kulit, kulit terbakar dan kanker kulit. Sedangkan penetrasi UVA sampai lapisan kulit dermis menyebabkan kerusakan sel kulit, 
mengurangi elastisitas kulit dan penuaan (Isfardiyana and Safitri, 2014).

Sejak dua dekade yang lalu material anorganik dalam ukuran nano telah diperkenalkan sebagai material tabir surya (Rigano and Lionetti, 2016). Material anorganik memiliki beberapa keunggulan, yaitu kecilnya potensi alergi, photostabilitas tinggi, dan spektrum yang lebar sehingga seringkali disebut sebagai material sunblock (Geoffrey et al., 2019). Material yang masih favorit sampai saat ini dan telah diproduksi secara komersial adalah $\mathrm{TiO}_{2}$ dan $\mathrm{ZnO}$ sebab material tersebut telah diterima oleh berbagai lembaga regulator, biaya yang murah dan secara alamiah tidak menyebabkan iritasi (Egambaram et al., 2020). Tetapi terdapat kelemahan pada penggunaan $\mathrm{TiO}_{2}$ dan $\mathrm{ZnO}$, yaitu kedua material tersebut bisa mengkatalis pembentukan radikal superoksida dan hidroksil, membangkitkan radikal bebas dan menginisiasi oksidasi yang beresiko terhadap kesehatan manusia (De Araujo et al., 2010).

Oleh karena itu perlu diteliti material anorganik lainnya yang bisa menjadi material UV filter / tabir surya. Pada saat ini dua mineral dari keluarga kalsium fosfat yaitu trikalsium fosfat dan hidroksiapatit (HA) sedang mendapat perhatian dari para peneliti untuk disintesis sebagai material tabir surya. Material kalsium fosfat yang paling menjanjikan di dunia kosmetik dan aplikasi peremajaan kulit adalah hidroksiapatit (Pal et al., 2020). Keunggulan hidroksiapatit adalah rendahnya efek pemutih, toleransi dermal yang tinggi, non toksik, tidak membentuk radikal bebas (Pal et al., 2020) menjadi booster SPF yang bisa mengurangi konsentrasi bahan kimia pada produk tabir surya (Hoang and Popa, 2014) dan memulihkan elastisitas serta kelembaban kulit (Sliem et al., 2017).

Material hidroksiaptit untuk material kosmetik tabir surya disintesis dengan berbagai metoda diantaranya : presipitasi basah kalsium hidroksida dengan asam fosfat (Amin et al., 2016; Sliem et al., 2017) presipitasi basah kalsium nitrat dengan ammonium fosfat (De Araujo et al., 2010) dan ekstraksi kering hidroksiapatit dari tulang ikan (Rozaini et al., 2018a; C. Teixeira et al., 2016; Piccirillo et al., 2012).

Balai Besar Keramik telah meneliti dan mengembangkan hidroksiapatit sintetik dengan metoda presipitasi basah kapur alam Padalarang dengan asam fosfat untuk kepentingan medik (Wahyudi et al., 2016). Hasil sintesis tersebut digunakan sebagai bahan prekursor untuk Carbonate Hydroxyapatite (CHA) yang merupakan bahan utama untuk periodental dan tulang buatan, komposit alumina-HA untuk tulang buatan dan dental blok, perbaikan tulang femoral (Rianti et al., 2020). HA yang dikembangkan BBK memiliki beberapa keunggulan diantaranya, kristal HA yang stabil pada kenaikan suhu kalsinasi, nilai brightness $83-92 \%$, whiteness berkisar antara 83-91\% (Damayanti et al., 2018), dan non toksik (Pridanti, 2020). Karakteristik fisis material UV filter secara umum meliputi ukuran partikel nano dan index refractive index $<2,9$ (Cole et al., 2016). Sedangkan untuk memenuhi standar FDA ada empat hal yang harus dipenuhi yaitu aktif pada range $290-400 \mathrm{~nm}$, tidak berbahaya bagi manusia dan lingkungan, terdaftar secara global, dan bahan tersebut bebas paten (Buescher, 1993).
Pada penelitian ini, akan dikaji material HA BBK dari hasil sintesis presipitasi basah sebagai material tabir surya, membandingkan sifat absorbansinya pada sinar UVA dan UVB dengan produk tabir surya yang lain dan memeriksa respon terhadap pemakaiannya pada kulit.

\section{Metode \\ 2.1. Preparasi Hidroksiapatit BBK}

Hidroksiapatit yang digunakan merupakan hasil sintesis di Balai Besar Keramik. Tahapan sintesis hidroksiapatit adalah sebagai berikut : kapur alam Padalarang disaring ukuran $5 \mathrm{~mm}$, hasil saringan dipadamkan dengan aquadest, rasio 1:1, diperam selama 48 jam sampai terbentuk milk lime. Milk lime digiling basah selama 24 jam sampai lolos 100 mesh. Larutan milk lime halus dialirkan ke dalam reaktor presipitasi dan ditambahkan asam fosfat dengan aliran 0,02 liter per detik. Rasio milk lime $\left(\mathrm{Ca}(\mathrm{OH})_{2}\right)$ dengan asam fosfat $\left(\mathrm{H}_{3} \mathrm{PO}_{4}\right)$ sesuai dengan rasio stoikiometri $\mathrm{Ca} / \mathrm{P}: 1,67$. Suhu reaktor dijaga $40^{\circ} \mathrm{C}$ selama proses presipitasi dengan selimut pendingin air. Mixer reaktor dijalankan dengan kecepatan $100 \mathrm{rpm}$ dari proses awal presipitasi dan selama 24 jam setelah proses presipitasi untuk mencegah pengendapan. Larutan hidroksiapatit dikeringkan untuk mendapatkan HA BBK dalam bentuk serbuk.

\subsection{Preparasi material tabir surya}

HA BBK dikalsinasi pada suhu $1200^{\circ} \mathrm{C}$, hasil kalsinasi digiling hingga 300 mesh. Sebanyak 0,1 gram dari masing-masing sampel dilarutkan dalam etanol pada beaker glass dan dimasukkan dalam sonikator selama 5 menit. Larutan HA dipindahkan ke dalam labu ukur $100 \mathrm{ml}$ dan ditambahkan etanol hingga batas. Sebanyak 2,5 ml dari larutan tersebut kemudian diambil dan diencerkan pada labu ukur $100 \mathrm{ml}$. Larutan dipindahkan pada kuvet dan disimpan dalam kotak hitam. Sebagai pembanding digunakan sunscreen komersil dengan merk "B" dan "S", $\mathrm{TiO}_{2}$, serta $\mathrm{ZnO}$.

\subsection{Pengukuran absorbansi}

Pengukuran absorbansi dilakukan dengan menggunakan PG Instruments UV/VIS spektrofotometer T80+. Grafik panjang gelombang maksimum diatur dari 270-400 nm. Absorbansi masing-masing sampel diukur pada panjang gelombang 290-320 nm dengan interval 5 nm.

\subsection{Perhitungan SPF}

Analisis untuk mengetahui kemampuan suatu bahan sebagai UV filter dilakukan secara in vitro dengan perhitungan menggunakan persamaan Mansur sebagai berikut :

$S P F($ spectrometry $)=C F \times \sum_{290}^{320} E E(\lambda) \times I(\lambda) \times a b s(\lambda)$

CF adalah faktor koreksi, EE $(\lambda)$ adalah efek eritemal 
spektrum $\lambda$, I $(\lambda)$ adalah intensitas sinar spektrum dan Abs $(\lambda)$ adalah nilai absorbansi. Nilai $\operatorname{EE}(\lambda) \times \operatorname{I}(\lambda)$ berupa nilai konstan yang telah ditemukan oleh Sayre dkk (1979) dapat dilihat pada Tabel 1.

Tabel 1

Nilai konstanta $\operatorname{EE}(\lambda) \times \mathrm{I}(\lambda)$ pada persamaan Mansur (Donglikar, M.M dan Deore, S. L., 2016)

\begin{tabular}{cc}
\hline Panjang Gelombang (nm) & EE X I \\
\hline 290 & 0,015 \\
295 & 0,0812 \\
300 & 0,2874 \\
305 & 0,3278 \\
310 & 0,1864 \\
315 & 0,0837 \\
320 & 0,0180 \\
\hline
\end{tabular}

\section{Hasil dan pembahasan}

Gambar 1 menunjukkan hasil karakterisasi XRD HABBK. Sudut $2 \theta$ puncak difraksi pada 25.9, 31.9, 32.9, 33.9 dan 39.80 di $2 \theta$ sesuai dengan bidang hkl (002), (211), (112), (300) dan (311) untuk hidroksiapatit menurut ICDD - PDF2 card 00-009-0432.

Nilai absorbansi hidroksiapatit pada panjang gelombang 290-320 $\mathrm{nm}$ tertera pada Tabel 2. Dengan menggunakan persamaan Mansur dan faktor koreksi sebesar 59,325 didapatkan nilai SPF hidroksiapatit adalah 8,82. Nilai SPF HA-BBK ini lebih tinggi dibandingkan dengan nilai SPF HA dari tulang ikan (C. Teixeira et al., 2016) yaitu sebesar 3,49 dan 4,08. Nilai SPF HA-BBK ini telah memenuhi syarat minimum SPF yang berlaku pada beberapa negara dengan nilai minimum SPF 2 dan maksimum SPF 50 (Pirotta, 2020).
Nilai SPF 8,82 menyatakan kemampuan HA-BBK untuk mengabsorbansi sinar UVB sebesar 87,5\% (Tahiliani and Shirolikar, 2018) berarti hanya 12,5\% dari sinar UVB yang diloloskan ke permukaan kulit.

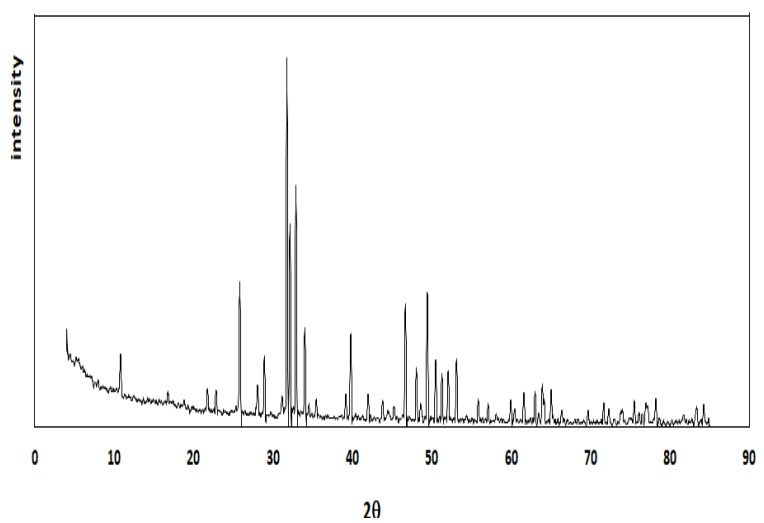

Gambar 1. Karakterisasi XRD HA-BBK

Tabel 2

Data Absorbansi Hidroksiapatit

\begin{tabular}{cccc}
\hline$(\boldsymbol{\lambda})$ & $\mathbf{E E}(\boldsymbol{\lambda}) \mathbf{x} \mathbf{I}(\boldsymbol{\lambda})$ & $\mathbf{A b s}(\boldsymbol{\lambda})$ & $\begin{array}{c}\mathbf{E E ~} \mathbf{~ I ~ x ~} \\
\mathbf{A b s}\end{array}$ \\
\hline 290 & 0,015 & 0,0381 & 0,0006 \\
295 & 0,082 & 0,0651 & 0,0053 \\
300 & 0,287 & 0,1722 & 0,0495 \\
305 & 0,328 & 0,1530 & 0,0502 \\
310 & 0,186 & 0,1509 & 0,0281 \\
315 & 0,084 & 0,1490 & 0,0125 \\
320 & 0,018 & 0,1416 & 0,0025 \\
\hline
\end{tabular}

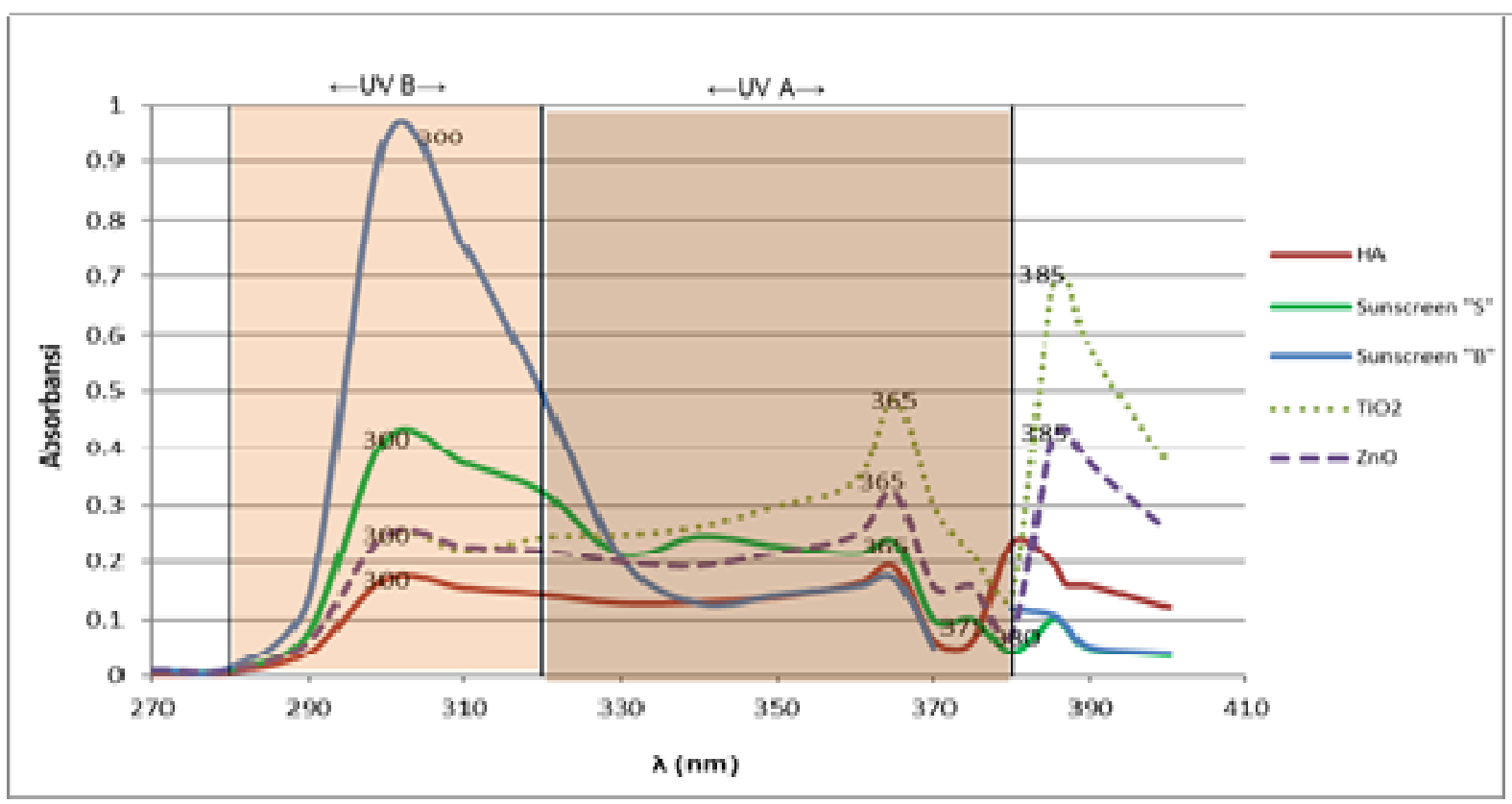

Gambar 2. Grafik spektrum serapan dari material tabir surya 
Pada Gambar 2 terlihat perbedaan spektrum serapan dari beberapa material, yaitu produk sunscreen "B", sunscreen "S", $\mathrm{TiO}_{2}, \mathrm{ZnO}$ dan $\mathrm{HA}-\mathrm{BBK}$ dan absorbansi maksimum untuk masing-masing berada pada panjang gelombang $(\lambda): 300 \mathrm{~nm}, 300 \mathrm{~nm}, 385 \mathrm{~nm}, 385 \mathrm{~nm}$ dan 380 $\mathrm{nm}$ secara berurutan. Absorbansi HA-BBK berada pada spektrum gelombang yang lebar yaitu dari 280nm410nm. Hal ini berbeda dengan hasil dari T S de Araujo, yaitu 200nm-340nm (De Araujo et al., 2010). Absorbansi terkuat HA-BBK terjadi pada panjang gelombang $(\lambda)$ lebih dari $370 \mathrm{~nm}$. Kedua hal tersebut menunjukkan bahwa material HA-BBK berpotensi menjadi material tabir surya pada semua spektrum UV (Rozaini et al., 2018b). Meskipun daya absorbansi HABBK masih inferior dibandingkan dengan semua material tabir surya yang ada pada Gambar 2., rentang spektrum HA-BBK telah memenuhi persyaratan FDA tahun 1993 yang menyatakan bahwa material tabir surya bisa dinyatakan sebagai anti-UVA bila mampu menahan UVA pada panjang gelombang $360 \mathrm{~nm}$ dan menunjukkan daya absorbansi di wilayah spektrum ini (De Araujo et al., 2010). Hal ini menunjukkan bahwa material HA-BBK memiliki potensi sebagai material tabir surya.

$\mathrm{TiO}_{2}$ dan $\mathrm{ZnO}$ merupakan bahan semikonduktor yang memiliki kemampuan sebagai fotokatalik. Hal ini menjelaskan mengapa $\mathrm{TiO}_{2}$ dan $\mathrm{ZnO}$ lebih baik dalam menyerap sinar UV dibanding hidroksiapatit. Sedangkan pada sunscreen komersial, komposisi didalamnya merupakan gabungan dari beberapa material UV filter sehingga menghasilkan absorbansi yang sangat baik.

\section{HA-BBK sebagai booster tabir surya pada material sunscreen "S"}

HA-BBK didopingkan pada sunscreen " $\mathrm{S}$ " dengan konsentrasi yang berbeda yaitu $10 \%, 25 \%$ dan $50 \%$ berat. Hasil doping HA-BBK ditunjukkan pada Gambar 3 Penambahan $10 \%$ HA menaikkan absorbansi sunscreen "S" pada panjang gelombang $300 \mathrm{~nm}$. Penambahan $25 \%$ HA nilainya hampir sama dengan $10 \%$ HA sedangkan penambahan 50\% menurunkan absorbansi sunscreen "S". Doping HA-BBK pada sunscreen "S" memberikan dampak yang positif terutama untuk penambahan $10 \%$ dan $25 \%$. Daya absorbansi sunscreen "S" meningkat baik di spektrum UVA maupun UVB.

Sunscreen "S" memiliki bahan aktif UV filter yang berjenis chemical sunscreen (Ethylhexyl Triazone, Diethylamino Hydroxybenzoyl Hexyl Benzoate, dll) yang konsentrasinya tidak diketahui. Penambahan hidroksiapatit bertujuan untuk meningkatkan nilai absorbansi. Penambahan hidroksiapatit yang berlebihan akan membuat bahan aktif dalam campuran tersebut didominasi oleh hidroksiapatit sehingga nilai absorbansi menjadi turun. Pada penelitian ini, dari ketiga variasi konsentrasi yang dilakukan menunjukkan bahwa penambahan $10 \%$ hidroksiapatit memberikan hasil yang paling optimum. Namun hasil akan berbeda tergantung pada komposisi bahan yang dicampurkan.

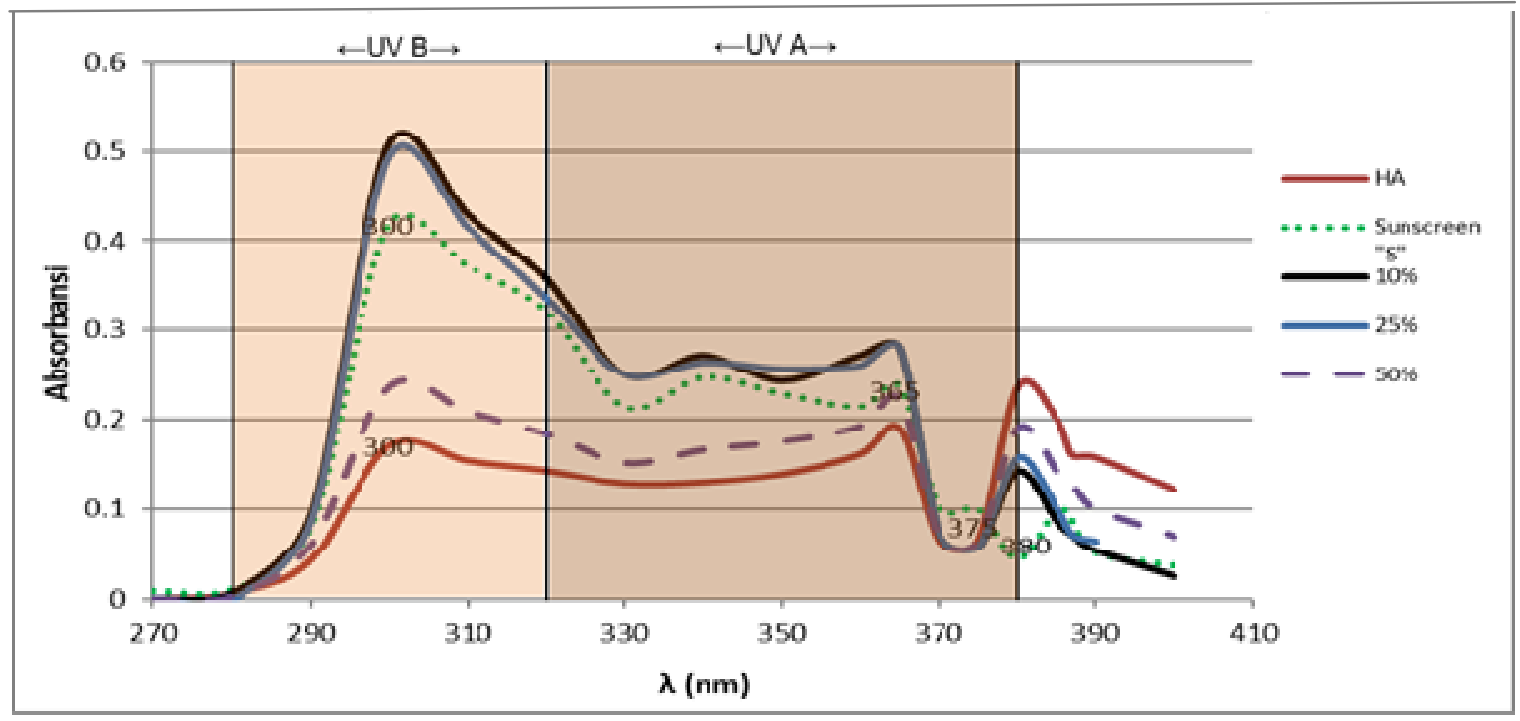

Gambar 3. Grafik panjang gelombang maksimum setelah penambahan hidroksiapatit pada sunscreen "S"

Hasil doping HA-BBK pada sunscreen "S" diujicoba responnya terhadap empat responden wanita dengan usia minimal 14 tahun . Pada tabel. 3. Terlihat bahwa hampir semua responden tidak mengalami keluhan gatal, kulit menjadi kemerahan, tidak berefek panas dan efek pemutihan tidak berlangsung lama, hanya terjadi 5-10 menit. Hal tersebut mengindikasikan bahwa HA-BBK tidak menyebabkan iritasi pada kulit dan permukaan kulit menerima dengan baik pelapisan material tabir surya. 
Tabel 3

Respon kulit terhadap pemakaian material sunscreen"S" dan doping HA-BBK

\begin{tabular}{|c|c|c|c|c|c|}
\hline No & Responden & Gatal & Kemerahan & Panas & Bercak putih / white cast \\
\hline 1 & A & Tidak & Tidak & Tidak & $\begin{array}{l}\text { Bercak putih cukup jelas pada awal } \\
\text { dioleskan, hilang dalam 5-10 menit }\end{array}$ \\
\hline 2 & B & Tidak & Tidak & Tidak & Tidak \\
\hline 3 & $\mathrm{C}$ & Tidak & Tidak & Tidak & $\begin{array}{l}\text { Terlihat samar pada awal dioleskan, } \\
\text { hilang dalam 5-10 menit }\end{array}$ \\
\hline 4 & $\mathrm{D}$ & Tidak & Tidak & Tidak & $\begin{array}{l}\text { Terlihat samar, hilang dalam 5-10 } \\
\text { menit }\end{array}$ \\
\hline
\end{tabular}

Pada Gambar 4.a. menunjukkan efek warna putih sesaat setelah pemakaian sunscreen "S" yang didoping HA dan setelah 3 jam pemakaian, efek putih menghilang dan warna kulit tidak berubah. Hal ini menguatkan hasil pada Tabel. 3 bahwa HA-BBK tidak memberikan efek pemutih pada permukaan kulit.

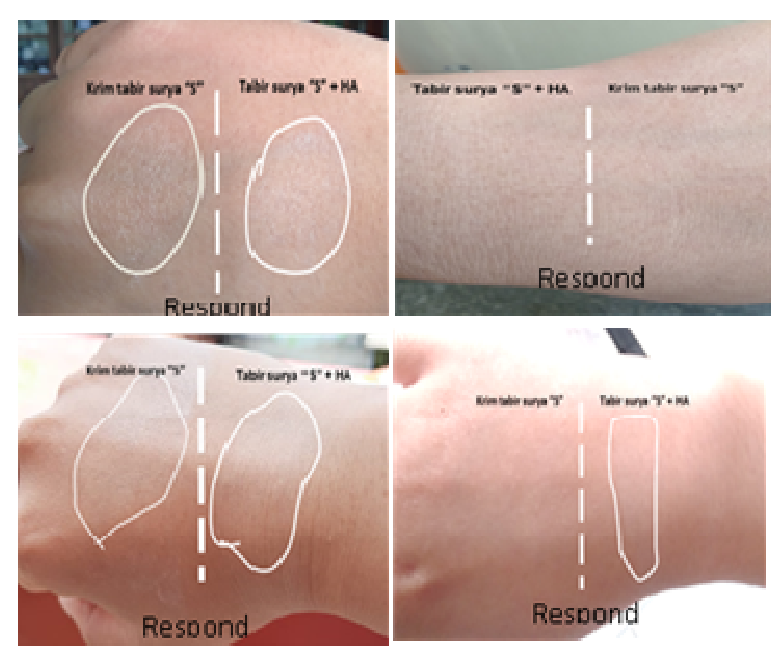

A

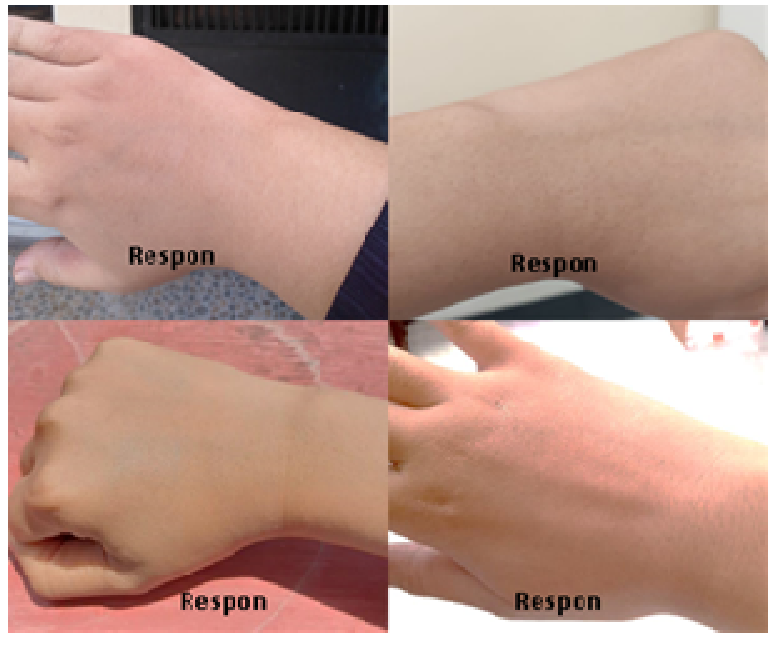

B

Gambar 4. Sesaat setelah krim tabir surya dioleskan pada punggung tangan (A) dan krim tabir surya dioleskan selama 3 jam (B)

\section{Kesimpulan}

Hasil XRD menunjukkan bahwa HA-BBK telah berhasil disintesis dengan metoda presipitasi basah menggunakan bahan baku kapur Padalarang serta asam fosfat food grade dan dikalsinasi pada suhu $1200^{\circ} \mathrm{C}$. HABBK sebagai material tabir surya memiliki angka SPF 8,82 yang artinya bisa menahan UVB sebesar $87,5 \%$. HA-BBK memiliki spektrum tabir surya yang lebar dari 280nm-400nm. Hasil doping HA-BBK pada krim sunscreen "S" mampu meningkatkan daya absorbansi UVA dan UVB. Respon pemakaian pada kulit tidak menunjukkan efek yang negatif, tidak menyebabkan gatal, kemerahan dan rasa panas. Pada beberapa kulit muncul bercak putih pada awal pemakaian, hal ini masih wajar ditemui pada beberapa produk tabir surya. Berdasarkan hasil tersebut menunjukkan bahwa HABBK berpotensi menjadi material tabir surya untuk kepentingan kosmetik. Penelitian lanjutan perlu dilakukan untuk meningkatkan angka SPF dan daya absorbansinya pada spektrum UVB dan UVA dan material emulsi atau krim yang sesuai dengan sifat HABBK.

\section{Ucapan terima kasih}

Penulis menyampaikan rasa terima kasih kepada Balai Besar Keramik, terutama personil Laboratorium Pengujian Kimia atas segala bantuan dan fasilitas yang diberikan dalam mendukung penelitian ini.

\section{Daftar Pustaka}

Amin, R.M., Elfeky, S.A., Verwanger, T., Krammer, B., 2016. A new biocompatible nanocomposite as a promising constituent of sunscreens. Mater. Sci. Eng. C 63, 46-51.

Buescher, L.S., 1993. Sunscreens and photoprotection, Otolaryngologic Clinics of North America. https://doi.org/10.1016/s0030-6665(20)30863-X

C. Teixeira, M.A., Piccirillo, C., Tobaldi, D.M., Pullar, R.C., Labrincha, J.A., Ferreira, M.O., L. Castro, P.M., E. Pintado, M.M., 2016. Effect of preparation and processing conditions on UV absorbing properties of hydroxyapatite-Fe2O3 sunscreen. Mater. Sci. Eng. C 71, 141-149.

Cole, C., Shyr, T., Ou-Yang, H., 2016. Metal oxide 
sunscreens protect skin by absorption, not by reflection or scattering. Photodermatol. Photoimmunol. Photomed. 32, 5-10. https://doi.org/10.1111/phpp.12214

Damayanti, H., Ratnasari, A., Wahyudi, K., 2018. Karakteristik kromatik bone ash sintetik berdasarkan suhu kalsinasi. J. Keramik dan Gelas Indones. 27, 66-76.

De Araujo, T.S., De Souza, S.O., De Sousa, E.M.B., 2010. Effect of $\mathrm{Zn} 2+, \mathrm{Fe} 3+$ and $\mathrm{Cr} 3+$ addition to hydroxyapatite for its application as an active constituent of sunscreens. J. Phys. Conf. Ser. 249.

Egambaram, O.P., Kesavan Pillai, S., Ray, S.S., 2020. Materials science challenges in skin UV protection: A review. Photochem. Photobiol. 96, 779-797.

Geoffrey, K., Mwangi, A.N., Maru, S.M., 2019. Sunscreen products: Rationale for use, formulation development and regulatory considerations. Saudi Pharm. J. 27, 1009-1018.

Hoang, B.T.X., Popa, I., 2014. Innovation in inorganic UV filters in sunscreen. Househ. Pers. Care Today 9, 35-39.

Isfardiyana, S.H., Safitri, S.R., 2014. Pentingnya melindungi kulit dari sinar ultraviolet dan cara melindungi kulit dengan sunblock buatan sendiri. J. Inov. dan Kewirausahaan 3, 126-133.

Pal, A., Hadagalli, K., Bhat, P., Goel, V., Mandal, S., 2020. Hydroxyapatite - a promising sunscreen filter. J. Aust. Ceram. Soc. 56, 345-351.

Piccirillo, C., Rocha, C., Tobaldi, D.M., Pullar, R.C., Labrincha, J.A., Ferreira, M.O., Castro, P.M.L., Pintado, M.M.E., 2012. A hydroxyapatite-Fe2O3 based material of natural origin as an active sunscreen filter. J. Mater. Chem. B 2, 5999-6009.

Pirotta, G., 2020. Sunscreen regulation in the world.
Handb. Environ. Chem. 94, 15-35.

Pridanti, K.A., 2020. Characteristic and cytotoxicity of hyrdroyapatite from Padalarang-Cirebon limestone as bone grafting candidate. Biochem. Cell. Arch. 20.

Rianti, D., Yulianti, A., Wahyudi, K., Damayanti, H., 2020. Limestone-based hydroxyapatite use for cavia cobaya femoral bone defects. Biochem. Cell. Arch. 2.

Rigano, L., Lionetti, N., 2016. Nanobiomaterials in galenic formulations and cosmetics, Nanobiomaterials in Galenic Formulations and Cosmetics: Applications of Nanobiomaterials. Elsevier Inc.

Rozaini, M.Z.H., Hamzah, H., Mohtar, N.F., Razali, M.H., Ibrahim, N.H., 2018a. Characterization of photoprotective hydroxiapatite from fringescale sardinella (Valenciennes, 1847) bones as natural sunscreen for cosmeceutical treatments. Key Eng. Mater. 792, 67-73.

Rozaini, M.Z.H., Hamzah, H., Poh Wai, C., Razali, M.H., M. Osman, U., Tuan Anuar, S., Che Soh, S.K., Binti Ghazali, S.R., Ibrahim, N.H., Fei, low C., Rahmah, S., 2018b. Calcium hydroxyapatite-based marine origin: Novel sunscreen materials for cosmeceutical treatments. Orient. J. Chem. 34, 27702776.

Sliem, M.A., Karas, R.A., Harith, M.A., 2017. A promising protected ascorbic acid-hydroxyapatite nanocomposite as a skin anti-ager: A detailed photoand thermal stability study. J. Photochem. Photobiol. B Biol. 173, 661-671.

Tahiliani, S., Shirolikar, M., 2018. Viva voce on sunscreens. Indian J. Drugs Dermatology 4, 92.

Wahyudi, K., Edwin, F., Sofiyaningsih, N., 2016. Sintetis dan karakterisasi bone ash sintetik dari bahan alam. J. Keramik dan Gelas Indones. 2. 